\title{
Maternal Rubella and Its Effect on the Foetus
}

\author{
J. A. DUDGEON \\ From the Department of Microbiology, The Hospital for Sick Children, and \\ The Institute of Child Health, Great Ormond Street, London
}

At the annual meeting of the Ophthalmological Society of Australia in 1941 Norman M. Gregg of Sydney contributed a paper entitled 'Congenital Cataract Following German Measles in the Mother'. In it he recorded a series of 78 infants with congenital cataract, including 13 of his own cases and 65 which had been seen in other parts of Australia (Gregg, 1941). In 67 of the 78 patients a history was obtained of the mother having had rubella during the first three months of pregnancy or just before conception. In many infants the cataracts were bilateral, and 44 had a congenital heart lesion, most commonly a patent ductus arteriosus. The infants were often small, ill nourished, and difficult to feed. Microphthalmia was common and irregular areas of pigmentation were seen in the retina of several of the patients in whom only one eye was affected. One case presented with a marked corneal haze in both eyes. Later, further cases were described in which the outstanding anomalies were cataracts, cardiac disease, deaf-mutism, dental defects, mental deficiency, and buphthalmos (Gregg, 1944). Gregg's observations were soon confirmed by Swan and his associates in South Australia (Swan, Tostevin, Moore, Mayo, and Black, 1943; Swan, Tostevin, and Black, 1946). They collected data on 101 cases of congenital malformations following maternal rubella in early pregnancy. The malformations most frequently encountered were: microcephaly $(62 \%)$, cardiac disease $(52 \%)$, deafmutism and deafness $(48 \%)$, cataract $(18 \%)$, and mental deficiency $(5 \%)$. During the next few years further confirmatory evidence of the association between maternal rubella and congenital malformations came from other Australian sources (Carruthers, 1945; Patrick, 1948), and from many parts of the world. In the United States cases were described by Reese (1944), Rones (1944), Erickson (1944), and Wesselhoeft (1949). In Great Britain cases were recognized by Hope Simpson (1944), Martin (1945, 1946), and by Clayton-Jones (1947) who collected details of 20 cases of deafness in which there was a history of maternal rubella within the first four months of pregnancy. Cases were also reported from Sweden (Grönvall and Selander, 1948), from Norway (Hagelsteen, 1946), and from Switzerland (Franceschetti and Bourquin, 1946).

During the period 1945 to 1960 many attempts were made to assess the risk of congenital malformations following rubella in pregnancy. Initial estimates by Swan (1949) put the figures as high as 80 to $90 \%$ in pregnancies complicated by rubella in the first trimester, but as the inadequacies of retrospective surveys became apparent and prospective studies were introduced in their place it became clear that the risk was much less. It was also clear from these and other surveys that foetal malformations were not associated with other virus infections contracted in pregnancy. At the time little was known about the natural history of rubella. That rubella was a virus disease had been postulated by Hess (1914) many years before, but this was not confirmed for a further 34 years when Hiro and Tasaka (1938) transmitted the disease to children with bacteria-free filtrates of nasopharyngeal washings from patients with rubella. Important information on the pathogenesis of rubella had been obtained by Krugman and Ward (1954) from early experimental studies in human volunteers. They had found that patients were infectious before the onset of the rash, that viraemia occurred, and that infection could take place without a rash. Further progress, however, was to be delayed for another 20 years due to the difficulty of studying a disease such as rubella without recourse to experimental studies in monkeys and human volunteers. The same obstacles applied at the time to the study of poliomyelitis and measles, and it was not until the early 1950's, following the pioneer work of Enders, Weller, and Robbins (1949) on the application of tissue culture to the study of poliomyelitis, that a major breakthrough in virology occurred.

In 1962 two reports appeared concurrently describing the isolation of rubella virus in tissue culture. Weller and Neva working at the Harvard School of Tropical Health, and Parkman, Buescher, 
and Artenstein from the Walter Reed Army Institute of Research produced clear-cut evidence that the virus had been successfully propagated in cell cultures of human amnion (Weller and Neva, 1962) and in primary African Green monkey kidney cultures (Parkman et al., 1962). These results were soon confirmed and within a short time diagnostic tests for rubella had been developed. Shortly afterwards rubella appeared in epidemic form in Great Britain in 1962-63, and in the late winter and early spring of 1964 in the eastern part of the United States. This epidemic proved to be one of the most extensive ever recorded (Cooper and Krugman, 1966), and inevitably many pregnant and susceptible women were exposed to infection. Later that year and in the early months of 1965 an increased number of congenital malformations was recognized at many different centres in the United States. In addition to malformations of the classical rubella syndrome type others showed evidence of a disseminated infection with involvement of many organ systems, with signs and symptoms not previously associated or recognized as part of the rubella syndrome. Were these in fact 'new' manifestations, possibly due to a new strain of virus, or had they occurred before? Much the same question arose in 1941 following the recognition of rubella malformations in the wake of the Australian epidemic of 1940. The answer on both occasions can probably be traced to the unusual epidemiological conditions prevailing at the time. In 1940, Australia was at war and many young adults of both sexes called up for war service were housed or working under conditions that favoured the spread of epidemic disease. The Australian rubella epidemic was particularly extensive and severe, as it was in England. Gregg (1941) records that many patients had extensive swelling of the glands of the neck, severe sore throats, and high fever, and involvement of the joints was a common feature. The average stay in hospital was eight days compared with four in the previous years. Because of the severity of the disease Gregg was for a time in doubt about the diagnosis of rubella. Later he became convinced that it was rubella, 'but that the epidemic differed greatly from the ordinary virus infection bearing that name'. There is little doubt that Gregg was the first to recognize the association between maternal rubella and defects, but it is equally certain that cases of the rubella syndrome had occurred before, though the association with maternal rubella had not been noticed. Several possible examples can be found in the literature. In 1813 Wardrop recorded the 'History of James Mitchell, a boy born blind and deaf with the account of the operation performed for the recovery of his sight'. These defects could well have been rubella in origin, and this may also have been the explanation for the case of deafness with pulmonary stenosis reported by Leuch (1892). Fraser (1964) considers that some of the cases of cataracts encountered in surveys of deaf children with retinitis pigmentosa may have been rubella in origin. Lancaster (1954) produced data from retrospective studies of increases in the births of deaf children at irregular intervals in England, Australia, New Zealand, and Iceland between the years 1893 and 1940. Beswick, Warner, and Warkany (1949) recorded three cases of infants with rubella-type defects seen at the Children's Research Foundation in Cincinatti in 1930 and 1936. The history of maternal rubella in early pregnancy is recorded. It is probable that similar reports could be found in the archives of many children's hospitals.

The situation in the United States in 1964-65 was not dissimilar to that of Australia in 1940. The epidemic was extensive and inevitably many nonimmune pregnant women became exposed to rubella. However, on that occasion the risk of foetal damage was known and the risk of rubella defects was to some extent expected. What was unexpected was the type and the multitude of congenital defects encountered. The fact that so many 'new' manifestations of rubella defects were recognized can probably be attributed to the size of the epidemic, the numbers of infants affected, and to the detailed clinical and laboratory investigations carried out while in hospital. The exact number of infants affected is not known, but it has been estimated that between 10,000 and 20,000 infants with congenital rubella malformations were born in the United States between 1964 and 1966 (Cooper and Krugman, 1966). The only consolation from this unfortunate episode was the fact that laboratory tests incorporating both virological and immunological techniques had been developed by the time the epidemic started. These, together with the awareness of the risk of rubella to the foetus, have led to the acquisition of much new knowledge both in regard to the clinical manifestations and to the pathology of foetal infection with rubella virus.

\section{Clinical Manifestations of Congenital Rubella}

Before the epidemic of 1964-65 the clinical features usually associated with the rubella syndrome were cataracts, cardiac defects, and deafness occurring singly or in combination. In addition affected children were often underweight at birth and retarded in development. Microcephaly was often present (Lundström, 1952, 1962). Following the 
1964-65 rubella epidemic in the United States many infants were born with congenital rubella defects, some of which later showed the classical symptoms of the 'rubella syndrome', such as cataract and cardiac defects, while others had a wide variety of signs and symptoms many of which were recognizable at birth or soon after. These included neonatal purpura and thrombocytopenia, hepatosplenomegaly, jaundice, hepatitis, bone lesions, anaemia, pneumonitis, myocardial damage, and central nervous system involvement. These new manifestations, which have been referred to as the 'expanded rubella syndrome' or 'acute disseminated congenital rubella of the newborn', will be considered together under the general heading of congenital rubella. Detailed accounts of the clinical, epidemiological, virological, and immunological investigations of many of these cases of congenital rubella have been recorded by a number of investigators including Plotkin, Oski, Hartnett, Hervada, Friedmann, and Gowing (1965b), Rudolph, Singleton, Rosenberg, Singer, and Philips (1965), Horstmann, Banatvala, Riordan, Payne, Whittemore, Opton, and Florey (1965a), Cooper, Green, Krugman, Giles, and Mirick (1965a), Bellanti, Artenstein, Olson, Buescher, Luhrs, and Milstead (1965), Korones, Ainger, Monif, Roane, Sever, and Fuste (1965), Lindquist, Plotkin, Shaw, Gilden, and Williams (1965), and Rubella symposium (1965).

In Fig. 1 is shown a summary of the main clinical features that may be found in recognized cases of congenital rubella. These figures, which have been compiled from numerous published reports and from the records of 120 cases seen at, or referred to, The Hospital for Sick Children, Great Ormond Street, London, provide a rough guide to the relative frequency of defects encountered in established cases of congenital rubella.

Multiple defects. These are extremely common in congenital rubella. In the Manson series (Manson, Logan, and Loy, 1960) 24\% of deformed children had more than one defect. In the 120 cases studied at, or referred to, The Hospital for Sick Children, $26(21 \%)$ had single defects, the commonest of which was either deafness or a patent ductus; $94(79 \%)$ had more than one defect. In many of the recently reported cases multiple defects were encountered (Rubella symposium, 1965). The risk of multiple defects is greatest when foetal infection occurs in the first 8 weeks of pregnancy.

Intrauterine growth retardation. A low birthweight as a sequel to maternal rubella was first recorded by Gregg (1941) and fully documented by Lundström in his prospective survey of the effects of maternal rubella in Sweden (Lundström, 1962). The gestational age is usually normal. Lundström found that at follow-up at 1 to 3 years of age $27 \%$ of infants with defects were subnormal in height and weight and had a small head circumference; $38 \%$ had delayed functional development. Between $\mathbf{5 0}$ and $80 \%$ of the cases seen following the United States epidemic had birthweights of less than $2500 \mathrm{~g}$. (Rubella symposium, 1965). In the series reported by Cooper et al. (1965a), 60\% of rubella infants fell below the 10th centile values and $90 \%$ below the 50th centile level. The mean birthweight with a normal gestational level was $2270 \mathrm{~g}$.

Cardiac malformations. These are the most common of all rubella defects. They are usually of the acyanotic or potentially cyanotic type, and about $50 \%$ are associated with rubella defects such as cataracts, deafness, and retinopathy. A patent ductus arteriosus is the most common lesion, and next in order of frequency are interventricular and interatrial septal defects and Fallot's tetralogy. A number of cases of coarctation or stenosis of the pulmonary artery and its branches have recently been reported as a manifestation of cardiac involvement in congenital rubella (Lindquist et al., 1965; Horstmann et al., 1965a; Pitt and Keir, 1965). Cases of renal artery stenosis have also been described (Menser, Dorman, Reye, and Reid, 1966).

Myocardial damage. Of 22 newborn infants investigated by Korones and his colleagues (Korones et al., 1965), 7 were found to have electrocardiographic evidence of myocardial damage. In two fatal cases studied histologically, extensive necrosis was found in the myocardium. Ainger, Lawyer, and Fitch (1966) recently reported a series of 47 infants with congenital rubella of whom 10 had electrocardiographic evidence of myocardial death, injury, or ischaemia. Seven infants had active myocardial disease, but in three infants the electrocardiographic changes at birth indicated that healing of the myocardial lesion had taken place in utero.

Eye defects. Cataracts are the next most frequent defects encountered. Approximately $70 \%$ of cataracts are bilateral and are commonly associated with other rubella defects. The cataracts are usually subtotal and appear as dense white opacities, often with a pearly centre surrounded by a zone of less dense opaque material and an outer peripheral zone of clear cortex. In others the contrast between the central and intermediate zones is less pronounced. A membraneous type of cataract may also be found. Cataracts may not appear for some weeks 


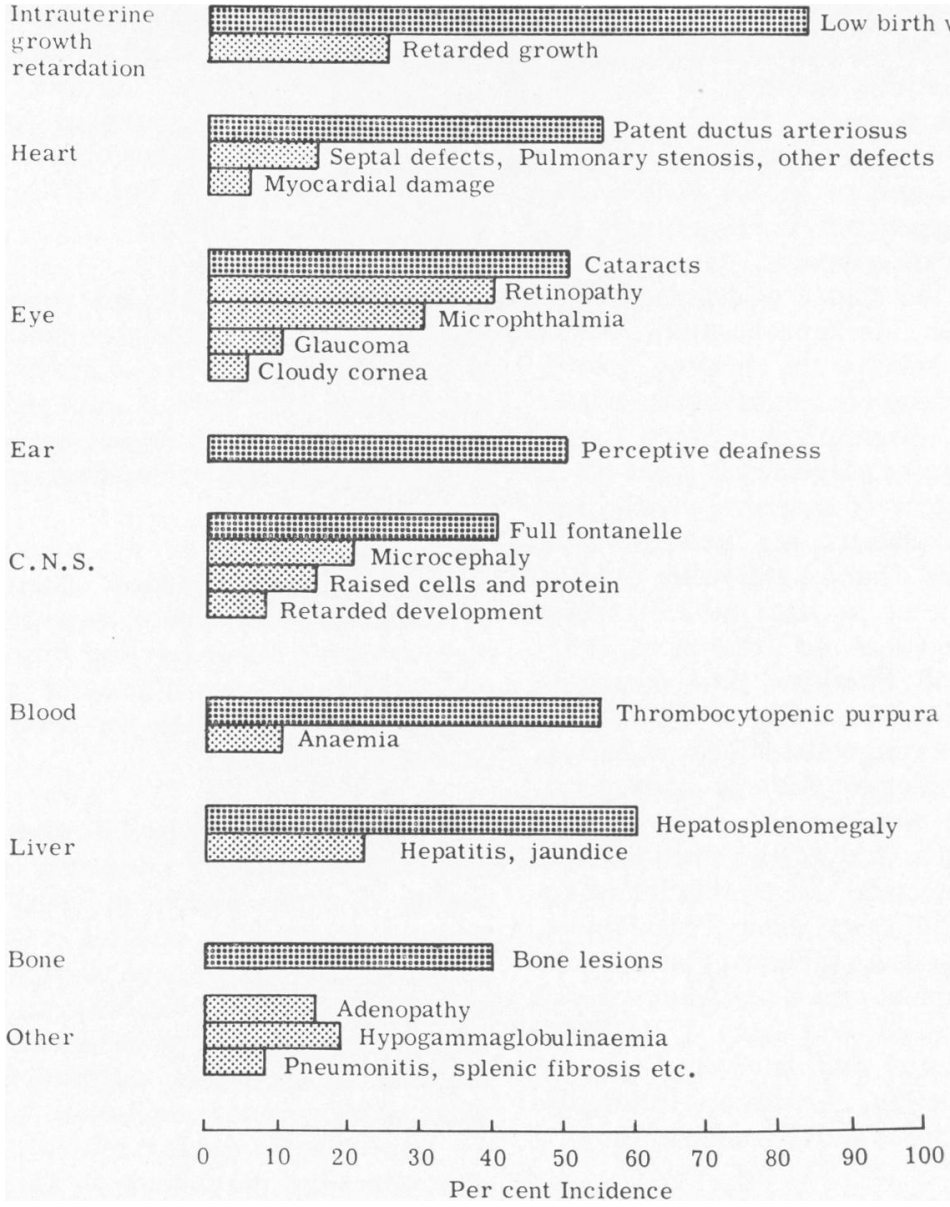

FIG. 1.-Clinical manifestations of congenital rubella: percentage incidence of major and minor defects in established cases.

after birth; those that are present at birth may subsequently increase in size during the early weeks of life (Giles, Cooper, and Krugman, 1965; Cooper et al., 1965a; Hambidge, Shaffer, Marshall, and Hayes, 1966).

Microphthalmia is common in congenital rubella; it is more evident in unilateral cases.

Pigmentary retinopathy is another common feature being most apparent in eyes without cataracts. The retinal lesions, which have been described as 'rubella retinitis' and 'pseudo-retinitis pigmentosa', result from a lack of pigment formation and not from an inflammatory reaction such as occurs in cytomegalic inclusion disease and in toxoplasmosis. Retinopathy seldom affects visual acuity unless lesions occur in the macular area.

Glaucoma is a rare complication of congenital rubella. Weiss, Cooper, and Green (1966) have recorded seven cases in eight of which other rubella type defects of varying intensity were present. In one case glaucoma was the only manifestation of congenital rubella. The cases presented with enlarged cloudy oedematous corneas with deep tense anterior chambers and raised intra-ocular tension. Glaucoma may not become apparent until later in infancy.

Corneal clouding without increase in ocular tension or corneal enlargement may also occur. It was first described by Gregg (1941). Further cases have been recorded by Weiss et al. (1966). This may last for several weeks but usually resolves spontaneously.

Other eye defects, such as strabismus, nystagmus, and coloboma have been described, but it is not known whether or not they are causally related to rubella. 
Hearing defects. The loss of hearing originally described as deaf-mutism is not absolute, and the term congenital perceptive deafness or profound childhood deafness, as suggested by Fraser (1964), is preferable to deaf-mutism. Hearing loss is due primarily to maldevelopment in the cochlea and organ of Corti, but degenerative changes may also occur. The vestibular apparatus is unaffected. Marked variation in the degree of hearing loss is encountered in rubella. In approximately $70 \%$ of cases of congenital rubella the hearing loss is bilateral; these latter cases are commonly associated with speech defects. Asymmetry is often found. Deafness should always be suspected in cases where there is a known history of maternal rubella and when other rubella defects are present. The incidence of perceptive deafness following the first trimester rubella may be as high as $25 \%$ when assessed at 5 to 7 years (Barr and Lundström, 1961; Jackson and Fisch, 1958; Sheridan, 1964) compared with $6 \%$ at 2 years (Manson et al., 1960). In the reports of the cases of congenital rubella following the United States' epidemic (Rubella symposium, 1965) scant reference was made to deafness as a clinical manifestation, as the infants were still too young for this to be detected. In a recent follow-up study of some of the cases from Philadelphia, Plotkin and his colleagues have shown that many of the features of the neonatal period, e.g. purpura and bone lesions, had receded, and signs of deafness, microcephaly, and mental retardation had become more prominent (Plotkin, Cochran, Lindquist, Cochran, Schaffer, Scheie, and Furukawa, 1967).

Purpura and thrombocytopenia. This is a common manifestation of disseminated congenital rubella in the newborn. Of 200 newborn infants, $70(35 \%)$ studied in New York City were found to have purpura and thrombocytopenia (Cooper et al., 1965a). Similar high figures were reported by Horstmann et al. (1965a) and Plotkin et al. (1965b). Reports before 1966 contain few references to purpura as a manifestation of congenital rubella. Lundström (1962) recorded three cases in the Swedish survey in which there were 51 cases of the rubella syndrome, but few were seen in the neonatal period. Lesions usually appear as discrete macules within 24 to 48 hours of birth and are most commonly seen on the face, trunk, and arms. In most cases the purpuric lesions fade within 7 to 10 days. Purpura may rarely occur much later in pregnancy, presumably due to exacerbation of symptoms from reactivation of latent virus. Platelet counts may range from 20,000 to 100,000 . In most instances platelet counts have returned to normal within four months (Cooper et al., 1965a). The duration of thrombocytopenia does not appear to be affected by corticosteroid therapy. Further observations on thrombocytopenic purpura in congenital rubella have been made by Banatvala, Horstmann, Payne, and Gluck (1965) and Bayer, Sherman, Michaels, Szeto, and Lewis (1965).

Hepatomegaly and splenomegaly. An enlarged liver and spleen are commonly found in cases of congenital rubella in the newborn, but this may not develop or be noticed until the second or third month of life. Both organs are usually enlarged but occasionally the enlargement is confined to one organ.

Hepatitis and jaundice. Jaundice may appear within the first 24 hours of life and is associated with high levels of direct-reacting bilirubin. Hepatitis without jaundice may also occur; the transaminase levels are usually raised for several weeks before returning to normal.

Bone abnormalities. Further evidence of the generalized nature of congenital rubella was the finding of bone defects in many newborn cases reported by Rudolph and his colleagues (Rudolph et al., 1965). These have since been reported by many other workers (Rubella symposium, 1965). The radiological changes are found in the skull and the long bones. They consist of poorly defined zones of provisional calcification and coarsening of the trabeculae in the metaphyses, and are seen in most bones but particularly in the proximal end of the tibiae and distal ends of the femur. In addition $x$-ray films of the skull may reveal a large anterior fontanelle with the anterior part of the fontanelle extending into the frontal bone and involving the metopic suture (Singleton, Rudolph, Rosenberg, and Singer, 1966). Radiological changes of bone involvement seldom persist for longer than three to four months, but may be found at the end of the first year of life. A case of congenital rubella with clinical and radiological evidence of osteitis has been observed (W. C. Marshall, K. Hayes, and A. H. Chrispin, 1966, personal observations).

CNS involvement. This may be found in the newborn with signs of a full anterior fontanelle and an increase in cells and protein in the spinal fluid (Plotkin et al., 1965b). Increased spasticity may also be encountered in the early months of life. The development of microcephaly, mental retardation, and electroencephalographic records (Rudolph et al., 1965; Singleton et al., 1966) indicates that the 
central nervous system may be severely affected following foetal infection.

Other manifestations. These include anaemia, both haemolytic and hypoplastic (Cooper et al., 1965a; Horstmann et al., 1965a); interstitial pneumonitis and splenic fibrosis (Plotkin et al., 1965b), rubella exanthem and lymphadenopathy (Hambidge et al., 1966), and hypogammaglobulinaemia (Soothill, Hayes, and Dudgeon, 1966). Unusual dermatoglyphic findings associated with rubella syndrome have been reported by Achs, Harper, and Siegel (1966), but these observations require further study. In all probability this list of minor manifestations will grow as further cases of congenital rubella are studied.

\section{Effect on the Foetus}

The early studies from Australia demonstrated the close association between rubella in early pregnancy and congenital malformation, but, on account of the retrospective method of analysis, the risk was exaggerated, mainly because they did not take into consideration the number of normal children that were born following maternal rubella. As a result of prospective studies it became clear that the incidence of foetal damage was much lower. The findings of several of these are shown in Table $I$. The details of 15 prospective studies summarized by Lundström (1962) are shown in the first column of Table I. In the second column the results of 4 of these 15 studies are shown separately as the methods of assessment were similar (Bradford Hill, Doll, Galloway, and Hughes, 1958). In the third and fourth columns are shown the results of the prospective studies carried out in Sweden in 1951 (Lundström, 1952, 1962) and in Great Britain during the period 1951-52 by Manson and her colleagues (Manson et al., 1960); in both instances matched controls were studied. On the whole there is broad agreement between the figures from the Swedish and British surveys, but the figures from a small prospective study in Paris (column 5) show the surprisingly high figure of $66 \cdot 6 \%$ for the incidence of malformation following first trimester rubella. The explanation for this is not clear. There is also an increased risk of death in utero following maternal rubella in the first trimester. The figures relating to spontaneous abortion and still-

\section{TABLE I}

Incidence of Congenital Malformations Following Rubella in Pregnancy. Data Obtained from Several Prospective Studies

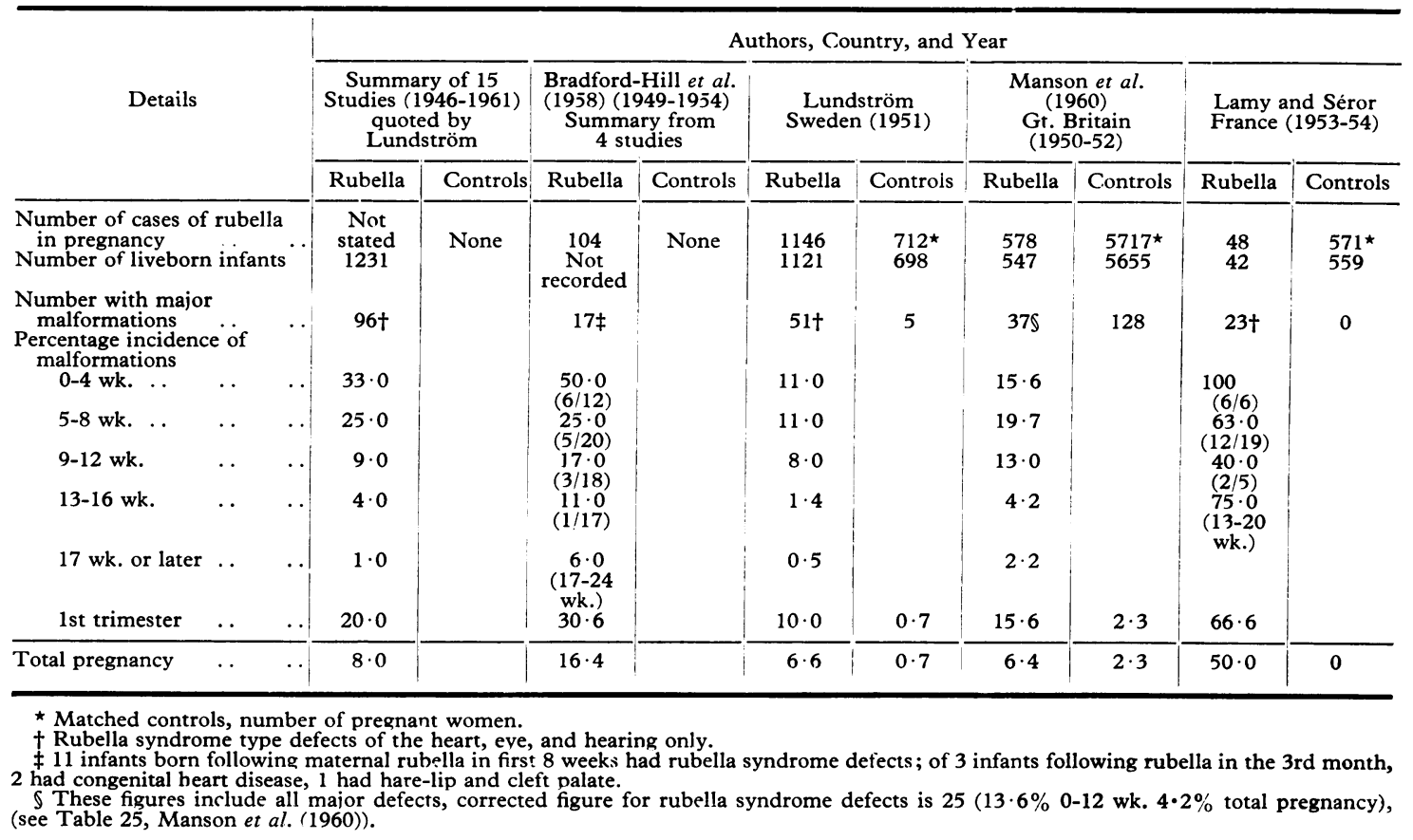


TABLE II

Effect of Maternal Rubella in Pregnancy ${ }^{\star}$

\begin{tabular}{|c|c|c|c|c|c|c|c|}
\hline \multirow[b]{2}{*}{ Time of Maternal Rubella } & \multicolumn{7}{|c|}{ Percentage Incidence of Effects of Foetal Damage } \\
\hline & Abortions & Stillbirths & $\begin{array}{l}\text { Liveborn } \\
\text { Infants }\end{array}$ & $\begin{array}{l}\text { Major Defects } \\
\text { in Liveborn } \\
\text { Infants }\end{array}$ & $\begin{array}{c}\text { Death } \\
\text { under } 2 \text { yr. }\end{array}$ & $\underset{2 \mathrm{yr} .}{\text { Alive at }}$ & $\begin{array}{l}\text { Major } \\
\text { Defects } \\
\text { at } 2 \text { yr. }\end{array}$ \\
\hline $\begin{array}{l}\text { Rubella up to } 12 \text { wk. } \\
\text { Controls } \\
\text { Rubella at } 13 \text { wk. and over } \ldots \\
\text { Controls } \\
\text { Co }\end{array}$ & $\begin{array}{l}5 \cdot 0 \\
2 \cdot 4 \\
0 \cdot 3 \\
0 \cdot 5\end{array}$ & $\begin{array}{l}4 \cdot 5 \\
2 \cdot 4 \\
3 \cdot 0 \\
2 \cdot 6\end{array}$ & $\begin{array}{l}90 \cdot 5 \\
95 \cdot 2 \\
96 \cdot 7 \\
96 \cdot 9\end{array}$ & $\begin{array}{r}15 \cdot 8 \\
2 \cdot 3 \\
2 \cdot 2 \\
2 \cdot 3\end{array}$ & $\begin{array}{l}6 \cdot 9 \\
2 \cdot 4 \\
2 \cdot 7 \\
2 \cdot 6\end{array}$ & $\begin{array}{l}83 \cdot 6 \\
92 \cdot 8 \\
94 \cdot 0 \\
96 \cdot 3\end{array}$ & $\begin{array}{r}13 \cdot 0 \\
1 \cdot 5 \\
1 \cdot 1 \\
1 \cdot 5\end{array}$ \\
\hline
\end{tabular}

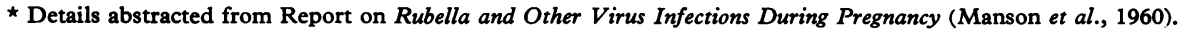

births from the British survey are shown in Table II.

The infant mortality rate is also increased in congenital rubella. This may be even higher in the disseminated type of infection. Cooper et al. (1965a) recorded a mortality rate of $29 \%$ in their series and Horstmann and her colleagues a figure of $14 \%$ (Horstmann et al., 1965a). Marked variation in the incidence of malformations may be obtained even with the prospective method of assessment. This is due in part to the methods of conducting the surveys, to the age at which the children are examined for the presence of defects, and to other factors as yet not understood. Despite this, these figures show that the greatest risk of foetal damage follows maternal rubella in the first 12 weeks of pregnancy, and as far as malformations are concerned the risk continues up to the 16th week. The risk is proportionately greater in the first than in the second and third months of pregnancy. This can be seen from the first three series reported in Table I, but is less marked in the Swedish and British surveys (Table I, columns 3 and 4). Similar findings were recently reported by Pitt and Keir (1965). In a study of 107 liveborn children born of 145 pregnancies, 20 children were observed with major rubella defects. The incidence of major defects for each of the first four months was $60 \%$, $33 \%, 33.4 \%$, and $5.7 \%$ with an over-all incidence of $23.8 \%$ for the first 16 weeks.

The age at which children at risk to intrauterine rubella infection are examined is important in assessing the over-all risk of foetal damage. In the initial examination in the British survey, the incidence of deafness at 1 to 3 years was $2 \%$ and of suspected deafness was $6 \%$. When many of these children were re-examined at 4 to 5 years of age the incidence of deafness was found to be $12.8 \%$, but no additional major defects such as cardiac or eye disease were discovered. In a final assessment on the children at 8 to 11 years of age Sheridan (1964) found that the incidence of minor defects, such as unilateral hearing loss and minor defects of vision, was $16 \%$. Taken as a whole the over-all effect of rubella infection in the first 16 weeks of pregnancy with foetal damage by abortion and stillbirths, major and minor defects, is approximately 30 to $35 \%$.

\section{Natural History of Rubella}

Numerous investigations extending over a period of 25 years have produced clear-cut evidence of the teratogenic effect of rubella virus. And they have done more than this: they have failed to reveal any evidence that any other virus has a similar teratogenic action. It is recognized that certain virus infections contracted in pregnancy may lead directly or indirectly to foetal damage, resulting in spontaneous abortions or to stillbirths. In others, transplacental infection may occur with evidence of clinical disease developing in the foetus or offspring at or soon after the birth, but with the exception of cytomegalovirus, which produces a somewhat different effect on the foetus from that of rubella, there is no evidence that any other virus infection contracted in pregnancy gives rise to foetal malformations (Manson et al., 1960; Rhodes, 1961; Dudgeon, 1966). That malformations may follow virus infections in pregnancy is not disputed, but these are most probably coincidental associations and not causative in nature.

The peculiar predilection of the rubella virus for the human foetus makes the diagnosis of rubella in pregnancy a matter of great importance, and yet making a diagnosis of rubella on clinical grounds can be difficult. Rubella lacks a specific sign or symptom which is pathognomonic. Rubella simulates other exanthematic diseases, notably measles, scarlet fever, enteroviral infections, such as ECHO 9, and the toxic erythemata. In addition marked clinical variation occurs in rubella. It has been known for some years that rubella can occur without a rash (Krugman, Ward, Jacobs, and Lazar, 1953), but it is only within the past few years that the importance of subclinical infection has come to be recognized and that patients with subclinical infection are infectious. It is for these reasons that a past history of rubella is of little value in a suspected 
case of rubella. Much can be done to confirm a clinical diagnosis of rubella by means of recently developed laboratory techniques for isolation of rubella virus and measuring antibody. These techniques have added greatly to our knowledge of the natural history of rubella because for the first time it has been possible to study the entire clinical course of the disease in parallel with virological and epidemiological studies. Details of such studies have been reported by Green and his associates (Green, Balsamo, Giles, Krugman, and Mirick, 1964, 1965a), and Brody and his associates in Alaska (Brody, Sever, McAlister, Schiff, and Cutting, 1965a; Sever, Brody, Schiff, McAlister, and Cutting, 1965a).

Some clinical aspects of rubella. The incubation period in rubella between the time of exposure and appearance of the rash is usually 16 days, but this may vary from 14 to 22 days. In many respects the incubation period is one of the most important phases of rubella infection because the patient is usually infectious for at least a week before the onset of the rash, at about the same time that virus appears in the bloodstream. Lymphadenopathy is the earliest sign of infection in rubella. In the studies by Green et al. (1964) lymphadenopathy could be detected regularly 7 days before the onset of the rash. In the rubella epidemic in the Pribilofs, Alaska, in 1963, studied by Brody et al. (1965a), lymphadenopathy was detected from 4 to 10 days in the majority of patients, and in a few for as long as 18 days before the rash. Lymphadenopathy is the most common manifestation of rubella in young children. Prodromal symptoms are not marked in rubella and are usually absent altogether in children in whom the first sign of infection is frequently fever and lymphadenopathy. In a typical case of rubella the rash appears first on the face and spreads rapidly downwards involving the neck and trunk. This usually lasts three days but marked variation occurs. The rash may last as long as 5 days, with a change from a maculo-papular rash to a bright red blush resembling scarlet fever. Brody and his colleagues (1965a) described a biphasic rash with complete regression in between.

Rubella and age of infection. A marked difference in symptoms in relation to age was noted in the epidemic in the Pribilofs (Brody et al., 1965a). In the age-group 0-14 between 30 and $50 \%$ had rubella with a rash and about the same proportion had fever and lymphadenopathy only; the remainder developed subclinical infection. In the age-group $15-19,90 \%$ had rubella with a rash.
Infectiousness of rubella. Virological studies have shown that virus can be recovered from the throat for about 7 days before the rash (Green et al., 1964). This coincides with the development of lymphadenopathy. It has been recovered as early as 13 days before the rash and is consistently present for 5 days after the rash. Virus persists in the nasopharynx for about 7 days after the rash in the majority of patients and may persist for as long as 14 days. Viraemia has been demonstrated as early as the seventh day before the rash and can be detected consistently by the fifth day before the rash. Viraemia ceases shortly after the appearance of the rash and the development of circulating antibody. Virus can also be demonstrated in the faeces and urine. Thus, the patient with rubella is infectious for about a week before and after the rash. Patients with subclinical infection are infectious and also develop viraemia. The main route of spread of rubella is by nasopharyngeal secretions. Infected urine and faeces present a potential source of infection but are probably of less importance. Infection of the foetus results from bloodstream spread.

Immunity to rubella. There is a close correlation between susceptibility to rubella and the absence of circulating antibody; conversely resistance is associated with the presence of specific neutralizing antibody. Antibody appears in the blood within 2 to 3 days after the rash and the titre reaches a peak level 21 to 28 days later. Neutralizing antibody persists unaltered in titre for many months, probably indefinitely. In studies in human volunteers it was found that only those without antibody could be infected with rubella virus. Even very low levels of antibody appeared to protect (Green et al., 1965a). Schiff, Smith, Dignan, and Sever (1965a) found a close correlation between the presence of antibody and resistance to rubella amongst hospital personnel exposed to epidemic rubella. Of 18 members of the staff under study, 16 had pre-existing antibody. None of the 16 had any illness or showed a change in antibody level. One individual without antibody developed a subclinical infection. In contrast, in a group of $\mathbf{1 6}$ student nurses without pre-existing antibody 6 developed rubella. Resistance from past infection was also demonstrated during the epidemic in the Pribilofs (Brody et al., 1965a). A rubella epidemic appeared in May 1963 after an absence of 20 years. The entire population under 20 years of age was susceptible and $87 \%$ of these developed rubella antibody. No cases of rubella with a rash developed in individuals over the age of 25 of whom $90 \%$ had pre-existing antibody. 
Epidemiology. Rubella has a world-wide distribution in the Northern hemisphere. Major epidemics occur somewhat irregularly about every 9 to 10 years and less extensive epidemics about every 3 to 5 years. Rubella does not show the same periodicity as measles. Rubella has its highest incidence in older children and young adults and is uncommon in infants and pre-school children. These views are confirmed by antibody studies which show a gradual rise in the incidence of antibody in children during school life (Lundström, Svedmyr, Hagbard, and Kaijser, 1967). Infection contracted at school is one of the principal sources leading to family infections. Antibody studies have shown that about 15 to $18 \%$ of women of childbearing age are still susceptible to rubella (Dudgeon, 1965; Sever, Schiff, Bell, Kapikian, Huebner, and Traub, 1965d), and that the incidence is somewhat higher amongst coloured populations. Under conditions of close contact, such as in institutions and amongst military recruits, rubella is highly infectious, especially if account is taken of subclinical infections (Horstmann, Riordan, Ohtawara, and Niederman, 1965b; Buescher, 1965).

Pathogenesis of congenital rubella. The availability of virological techniques has been particularly rewarding in studying the mode of spread of virus from mother to foetus and the nature and consequence of foetal infection. The various stages in the pathogenesis of rubella are illustrated in Fig. 2.

Maternal viraemia. From the point of view of foetal infection, viraemia is the most important phase in the maternal disease. As this occurs at such an early stage in the disease process, the foetus is probably infected at the time of the rash, or shortly afterwards, depending on the length of viraemia in individual cases.

Placental-foetal infection. Selzer $(1963,1964)$ recovered rubella virus from placental tissues in four cases, and from one foetus from aborted material, following maternal rubella in the first trimester. Histological evidence was also obtained of inclusion bodies in foetal and decidual cells. Kay, Peppercorn, Porterfield, McCarthy, and Taylor-Robinson (1964) demonstrated virus in the lungs of a 23-weekold foetus removed by hysterotomy following maternal rubella at the 5th week. Heggie and Weir (1964) also noted the persistence of virus in foetal tissues. The relation between maternal rubella and persistent placental-foetal infection has been carefully studied by Alford and his co-workers (Alford, Neva, and Weller, 1964; Alford and
Kanich, 1966). They isolated rubella virus from the products of conception of $46 \%$ of 68 women whose pregnancies were terminated following rubella in the first trimester. The isolation rate from the placentae was $47 \%$ and from the foetuses $26 \%$. Significant differences were noted in the isolation rate in relation to gestational age. Following rubella in the first three weeks it was $14 \%$; in the 5 th to 6 th week $73 \%$; in the 7 th to 8 th week $50 \%$; and in the 9 th to 16th between 31 and $33 \%$. Most of the foetal isolations were made from cases in which rubella had occurred in the first 8 weeks of pregnancy, whereas placental isolations were made both before and after the 8th week. In a study of 26 infants it was found that 19 out of the 20 infants exposed to intrauterine rubella in the first 8 weeks had signs of congenital rubella, and virus was isolated from 9. Following rubella in the second 8 weeks, only 2 out of 6 infants had clinical signs of congenital rubella and none were found to be excreting virus (Alford and Kanich, 1966). Horstmann and her colleagues (1965a) also recovered virus with greater frequency from foetuses when maternal rubella had occurred in the first eight weeks. Virus has been recovered from numerous individual foetal organs, such as the eye, intestine, kidney, liver, spleen, heart, and lung (Alford et al., 1964; Cooper et al., 1965a). Heggie (1966), however, failed to demonstrate any relation between the frequency of foetal infection and gestational age.

Postnatal infection in congenital rubella was first demonstrated by Alford et al. (1964) who recovered virus from 4 infants, aged 1 to 18 weeks, with congenital rubella. This finding has been confirmed by numerous investigators (Plotkin et al., 1965b; Cooper et al., 1965a; Korones et al., 1965a ; Horstmann et al., 1965a). In fatal cases of congenital rubella virus has been recovered from virtually every organ examined (Cooper et al., 1965a). Similar findings of a widespread disseminated infection have been reported by Bellanti et al. (1965) who found especially high concentrations of virus in the lymphoreticular tissues, kidney, and cataractous tissue. The extent of virus invasion also appears to be related to some extent to the gestational age at which maternal rubella occurred. The severe form of disseminated congenital rubella is seen more often, but not exclusively, following rubella in the first 8 weeks (Cooper et al., 1965a; Horstmann et al., 1965a; Lindquist et al., 1965). Foetal infection leading to congenital rubella defects and postnatal virus excretion has been described following inapparent maternal illness (Avery, Monif, Sever, and Leikin, 1965).

Subclinical infection can also occur following intrauterine rubella. Studies by Schiff, Sutherland, 
Light, and Bloom (1965b) showed that 43 of 300 infants $(14 \%)$ born of women exposed to rubella in the first trimester were excreting virus at birth. Of these, 33 had no detectable abnormalities at birth, but it remains to be seen whether any rubella defect such as deafness can be detected in any of these infants at subsequent examinations. Further evidence of subclinical infection in rubella was obtained from serological studies carried out by Butler, Dudgeon, Hayes, Peckham, and Wybar (1965) on children aged 2 to 4 years who were exposed to rubella in utero. The incidence of rubella antibody in this group of children without observable defects was approximately 10 times as frequent as in random sera taken from normal children of the same age. In most instances maternal infection had occurred between the 9 th and 16 th week of pregnancy. The foetus may escape infection altogether even though exposure to the maternal disease occurs at the most susceptible stage in development (see Fig. 2). There is now good statistical, clinical, and virological data to indicate that the risk to the foetus during the first trimester is not uniform. Whether this is due to the development of the placenta as a barrier or to the capacity of the foetus to resist infection has yet to be determined.

Virus can be recovered from the nasopharynx of about $60-80 \%$ of cases of congenital rubella infants at birth (Cooper et al., 1965a; Horstmann et al., 1965a), from about $30 \%$ at 6 months, and $7 \%$ at 10 months. Very few are found to excrete virus after the first year of life. Virus can be recovered regularly from the nasopharynx and less regularly from the urine. It can also persist for long periods in cataractous tissue (Reid, Murphy, Gillespie, Dorman, Menser, Hertzberg, and Harley, 1966), in the liver (Hambidge et al., 1966), and in the spinal fluid (Monif and Sever, 1966).

Congenital rubella is a contagious disease. This was first shown by Cooper et al. (1965b) and has since been confirmed by numerous observers (Schiff et al., 1965b; Hambidge et al., 1966). Although it appears that in most cases close contact is required for transmission of rubella in children and adults, the risk is potentially greater with infants with congenital rubella on account of the amount of virus excreted in the nasopharynx and urine.

The response to infection acquired in utero differs from infection with rubella acquired after birth. The main difference lies in the chronicity of infection with persistence of virus for many months after birth. This does not occur in childhood or adult rubella. A further difference is in the character of the immunological response. Plotkin, Dudgeon, and Ramsay (1963) showed that infants and young children with the rubella syndrome aged 2 months to 10 years had high titres of rubella neutralizing antibody. Similar findings were reported by Weller, Alford, and Neva (1964). In further studies it was shown that the neutralizing antibody titre in rubella infants was equal to or greater than that of the mother, and that it persisted at the same high level throughout the first year of life (Dudgeon, Butler, and Plotkin, 1964). Other viral antibodies transferred across the placenta, and presumably maternal in origin, decline at the expected rate and have largely disappeared by the 6th to 9 th month of life. The persistence of neutralizing antibody which occurs in about $95 \%$ of cases of congenital rubella is sufficiently constant to permit a retrospective diagnosis of intrauterine infection to be made (Dudgeon et al., 1964; Dudgeon, 1965; Weller et al., 1964; Butler et al., 1965; Plotkin et al., 1967). The reason why approximately $5 \%$ of infants with congenital rubella do not develop antibody is not understood. This may be due to lack of persistence of virus, to the development of immunological tolerance in a few cases, or to infection with some agent other than rubella.

Differences in the physicochemical nature of the antibody in congenital rubella and that of normal infants have been demonstrated by Alford (1965) and Bellanti and his colleagues (1965). These workers have shown that serum from infants with congenital rubella at or soon after birth contains IgM (19S) antibody and IgG (7S) antibody passively acquired from the mother. The IgM antibody persists but the IgG declines during the first few months of life and is then replaced by the infant's own IgG antibody. In sera from rubella-infected and non-rubella foetuses the antibody was found to be IgG. At the time of birth, IgM had appeared in the serum of rubella-infected infants but not in the normal infants (Alford, 1965). Quantitative estimation of the immunoglobulins in 22 cases of congenital rubella in the first year of life carried out by Soothill et al. (1966) confirmed these qualitative findings, that production of rubella antibody probably begins in utero and is predominantly IgM in character. The IgM was abnormally high in nearly all the children studied, particularly in those from whom virus was isolated. The levels remained high throughout the first year of life. Most of the IgG values were also rather high, but 6 had very low values: in 4 of these patients there was evidence of hypo- $\gamma$-globulinaemia and 2 of these suffered from repeated infections characteristic of the antibody deficiency syndrome. Thus it appears that the foetus exposed to intrauterine rubella is not, as might be expected, rendered immunologically 
tolerant in the accepted sense of the term in view of the fairly constant finding of neutralizing antibody after birth. The normal pattern of response, however, differs from the normal development of immunological competence in the early and sustained IgM response. The persistence of virus in the presence of antibody points to a defect in the cellular immune mechanism.

These findings relate to neutralizing antibody. The development of complement-fixing (CF) antibody appears to be somewhat different. A preliminary report by Lindquist et al. (1965) showed that only 1 of 6 infants with congenital rubella had demonstrable complement-fixing antibody during the first 8 months of life. Similar findings have been reported by Stern (1965) and Sever, Huebner, Fabiyi, Monif, Castellano, Cusumano, Traub, Ley, Gilkeson, and Roberts (1966). Plotkin and his colleagues (1967) report that the incidence of congenital rubella infants with positive CF complement-fixing antibody titres reaches a peak towards the end of the first year of life and then falls off again. Recent studies by Hayes, Dudgeon, and Soothill (1967) indicate that the complement-fixing antibody response is not as uniform as with neutralizing antibody. In some cases CF antibody was present at birth and persisted unaltered in titre for the first 6 to 9 months of life, in others it appeared to decline during the first few months and then reappeared.

Pathology of congenital rubella. The histopathological changes are of two main types. First, there are those due to retardation or inhibition of cell growth, and secondly, destruction of formed organs due to cellular necrosis. Both types can occur together. It has been shown in tissue culture experiments that the growth of rubella virus causes inhibition of mitotic activity in cells derived from the thymus, kidney, and pituitary (Plotkin, Boué, and Boué, 1965a). The arrest of mitosis might therefore lead to arrest of growth of an organ which would remain small in size, or to a structural defect in a developing organ such as the organ of Corti. Naeye and Blanc (1965) have recently shown in a study of 15 infants with congenital rubella that the small size of these infants and of certain organs, such as the brain, adrenals, and thymus was due to a subnormal number of cells. Inhibition of cell growth due to virus multiplication during the phase of organogenesis seems to be the most probable explanation for malformations. A secondary change resulting from cell necrosis may occur at the time of initial infection or at a later stage in development. For this to happen the virus still has to gain entry into susceptible cells, i.e. in the first trimester, but the damage may not occur until later due to growth of virus which has persisted in infected cells. Friedmann and Wright (1966) have described secondary degenerative changes in the cochlea duct and fully developed organ of Corti in rubella-infected foetuses and infants. Profound inflammatory changes were also present. Myocardial damage due to necrosis and fragmentation of muscle fibres has been described by Korones et al. (1965). Little inflammatory response was noted in these cases. Necrosis of paraventricular white matter with perivascular cuffing and minimal inflammatory changes have been described in the brain of fatal cases by Plotkin et al. (1965b). In the liver, changes indistinguishable from those seen in neonatal giant cell hepatitis have been described (Plotkin et al., 1965b; Lambert, Stern, and Wellsteed, 1965). The changes in the parenchymal cells and infiltration of mononuclear cells may be diffuse or focal. Thickened pulmonary alveolar septa and splenic fibrosis have been described, which point to an inflammatory process of long standing. Cases have been reported from Jamaica in which there was histological evidence of nephrocalcinosis, congenital glomerulosclerosis, cerebral calcification, and atrophy of the thymus (Thorburn and Miller, 1967). Abnormalities in which fully developed organs are damaged are more akin to the changes seen in cytomegalovirus infection and are somewhat different from the malformations that occur during organogenesis in congenital rubella.

\section{Laboratory Diagnosis of Rubella}

Laboratory tests have now reached a stage in development when they can usefully be employed in the diagnosis of suspected cases of rubella in pregnant women and of cases with whom they have been in contact (Plotkin, 1964). Two methods can be employed.

(1) Virus isolation is the principal method of diagnosis of rubella. The virus can be cultured in a number of different cell culture systems but those most commonly employed for diagnostic purposes are primary African green monkey kidney (AGMK) cultures (Buescher, 1964) and the RK 13 transformed line of rabbit kidney cells (McCarthy, TaylorRobinson, and Pillinger, 1963; Dudgeon et al., 1964). Although virus is present in the nasopharynx for about a week before and after the onset of the rash, and is also present in the urine and faeces, in practice, diagnosis is best attempted by examining nasopharyngeal swabs collected within four days of the rash. In these circumstances virus can be recovered from about $85-90 \%$ of cases of rubella. The final identification of a virus as rubella may take about 14 
days, or even longer in cases when it is necessary to subculture the specimens, but it may be possible to give a preliminary report in 7 to 9 days if the inoculated cell cultures show suspicious changes on primary culture.

(2) Serological tests to determine the patient's immune status to rubella are best carried out on paired specimens of sera. Acute-phase sera should be collected preferably within 3 to 4 days and not later than 7 days after the onset of the rash, and a second specimen about 2 weeks after the first.

(a) Neutralizing antibody can be measured by means of the same cell culture systems as used for virus isolation. In AGMK cultures antibody is measured by means of the interference-inhibition phenomenon (Buescher, 1964) or in RK 13 cells by means of cytopathic-inhibition (McCarthy et al., 1963; Dudgeon et al., 1964). Neutralizing antibody appears within a few days of the rash, increases rapidly in titre by the end of the first week, and reaches a plateau level at about 21 to 28 days after the rash. It appears to persist unaltered in titre for many years and probably indefinitely.

(b) Complement-fixing antibody can be measured by means of a microtechnique with a rubella $\mathrm{CF}$ antigen described by Sever and his colleagues (Sever et al., 1965b). Other workers have also found complement-fixation useful in the diagnosis of rubella (Stern, 1965; Plotkin et al., 1967). CF antibody in rubella appears slightly later than neutralizing antibody and may not reach a peak titre until about one month after the onset of the rash. It is more labile than neutralizing antibody and the titres decline after two to five years.

(c) An indirect fluorescent antigen-antibody technique has been described (Brown, Maassab, Veronelli, and Francis, 1965), which is useful as a screening test for a large number of sera.

(d) A haemagglutinin-inhibition (HAI) test has recently been described, which should greatly facilitate the serological diagnosis of rubella (Parkman, Meyer, and others, 1966).

Serological diagnosis of rubella is best made by means of the neutralization and complementfixation tests carried out in parallel. Four main patterns of antibody response may be encountered. If both sera collected at the appropriate time interval are devoid of rubella antibody, the diagnosis of rubella is improbable. If a rising titre to both neutralizing and complement-fixing antibodies can be demonstrated the diagnosis of rubella is certain. Recent infection can be considered highly probable if a high titre of both neutralizing and complementfixing antibody is found. On the other hand the finding of neutralizing antibody with little or no CF antibody is suggestive of a past infection, but the interpretation of these tests is extremely difficult unless sera are collected at the correct times. Interpretation is even more difficult with single serum specimens.

Diagnosis of congenital rubella. The same methods are used as in the diagnosis of childhood and adult rubella. In addition to nasopharyngeal specimens, urine specimens should be collected and inoculated into cell cultures. In fatal cases tissue from as many organs as possible should be examined. The finding of antibody in infants between 6 months and 4 years of age is strongly suggestive of intrauterine rubella. The presence of raised levels of $\operatorname{IgM}$ in infancy or of rubella antibody in the $\operatorname{IgM}$ fraction provides additional confirmatory evidence.

\section{Preventive Measures}

(a) General. A pregnant woman should avoid contact with a case of rubella. This is easier said than done but special precautions should be taken to prevent contact with infants with congenital rubella who are in most cases highly contagious for the first few months of life. The immune status of nursing and other staff caring for these infants and other cases of rubella should be determined by serological tests.

(b) Specific prophylaxis. The risk to a pregnant woman from rubella is clearly related to a primary infection occurring in the first 12 to 16 weeks of pregnancy. Proven second attacks are exceedingly rare and there is overwhelming evidence of a solid and long-lasting immunity following rubella. It also seems clear that resistance is mediated through the presence of circulating antibody, and an additional factor of importance is that rubella, as with measles, appears to be caused by a single strain of virus. On theoretical grounds, therefore, there is a sound basis for prevention by some form of immunization.

Passive immunization with plasma, serum, or $\gamma$-globulin has been used as a method of prevention of rubella for the past 25 years, but the results of numerous trials, recently reviewed by Green et al. (1965b), have shown varying degrees of success in preventing clinical rubella. There are several probable explanations for this. It may be a question of dosage or of the rubella antibody content of the preparation employed. Successes or failures of $\gamma$-globulin therapy must be viewed against the natural history of rubella, with its prolonged period of infectiousness and early viraemic state (see Fig. 2) which occurs well before the onset of symptoms, added to which there is the further problem of sub- 
clinical infection and of determining when a patient was first exposed to infection.

Controlled trials in children with pooled $\gamma$ globulin have in most cases shown a substantial degree of protection against clinical rubella (Landon, Bess, Davidsson, Foote, and Muckenfuss, 1949; Korns, 1952; Grayston and Watten, 1959; McDonald, 1963). The attack rate in several thousand pregnant women given $\gamma$-globulin appeared to be reduced in a trial in England between 1954 and 1961 (McDonald, 1963). The attack rate in 2700 pregnant women given $750 \mathrm{mg}$. was $1.48 \%$, and in 3278 given $1500 \mathrm{mg}$. was $1 \cdot 13 \%$. The only control datum available for these figures was an observed attack rate of $3.7 \%$ in untreated women in a family survey carried during roughly the same period (Watson and McDonald, 1963). However, these observations and those of Lundström et al. (1962, 1965) refer to the reduction in attack rates of clinical rubella. It cannot be concluded from these trials that because the mother escapes infection the foetus will be protected. Subclinical infection with viraemia could still affect the foetus. This aspect of the problem has recently been studied by Green and his colleagues $(1964,1965 a)$. In a group of 33 susceptible children exposed to experimental and natural infection, $\gamma$-globulin in a dosage of $0.26 \mathrm{ml}$. to $0.44 \mathrm{ml} . / \mathrm{kg}$. failed to prevent rubella or viraemia. The length of viraemia appeared to be reduced in treated children compared with untreated controls. In a trial in schoolboys in Alaska it was found that $\gamma$-globulin halved the total infection rate as determined serologically and reduced the clinical attackrate to a quarter. A large dose of $0.55 \mathrm{ml} . / \mathrm{kg}$. body weight was used and most of the injections were given before exposure (Brody, Sever, and Schiff, 1965b). $\quad \gamma$-globulin given to mothers 6 and 7 days before the onset of the rash failed to prevent foetal infection (Cooper et al., 1965a). On the other hand Sever and his colleagues found that $\gamma$-globulin (15 to $20 \mathrm{mg}$. within 5 days of exposure) materially reduced the clinical attack rate in the mother, but the outcome of the pregnancies has not yet been studied beyond the neonatal period (Sever, Nelson, and Gilkeson, 1965c). The effect of $\gamma$-globulin given to 30,746 pregnant women exposed to rubella during pregnancy in the period 1956-62 has recently been studied by McDonald and Peckham (1967). The attack rate in family contacts was $1.95 \%$. Figures in untreated women were not available but they would probably have been considerably higher. The incidence of heart disease and deafness in the offsprings of the 610 women who contracted rubella was $18 \%$. No cataracts were observed, but only $13 \%$ of the women in the first 8 weeks of pregnancy contracted rubella. There appeared to be no excess of rubella-type defects in treated women who were in contact but who escaped infection. At the best $\gamma$-globulin given before exposure will reduce the clinical attack rate and thereby reduce the risk of foetal infection. If clinical disease develops in the mother the risk to the foetus is probably the same as in unprotected women.

Active immunization. The only answer to the prevention of foetal malformations lies in inducing a state of active immunity to rubella before pregnancy. The recent acquisition of knowledge concerning the preparation and safety testing of viral vaccines by tissue culture techniques has opened the way to the development of a rubella vaccine. Of the two alternatives, a killed or attenuated vaccine, it can be argued that the former would have the advantage of producing immunity without the risk of causing infection, subject to satisfactory safety tests. A killed vaccine would almost certainly require a series of spaced injections and the immunity would probably be of shorter duration than with an attenuated vaccine. On the other hand an attenuated vaccine might produce a transmissible infection in vaccines, which would be a hazard to any pregnant woman exposed to a recently immunized individual.

More recently Parkman and Meyer and their associates have reported their preliminary observations on the attenuation of rubella virus in cell culture. After serial subculture in monkey kidney cell cultures, two strains of rubella virus were developed which showed alterations in their biological properties compared with wild virulent strains of virus (Parkman, Meyer, Kirschstein, and Hopps, 1966). In rhesus monkeys the attenuated virus showed no evidence of pharyngeal infection or of viraemia and no contact infections occurred, but 13 out of 14 of the animals developed an immune response. One of the high passage levels of attenuated virus has since been administered to institutionalized children (Meyer, Parkman, and Panos, 1966). None of the 34 vaccinated children developed any illness and all developed neutralizing antibody. Rubella virus was isolated from the nasopharynx of a number of children, but the amount of virus present was low compared with that observed in natural rubella. No evidence was obtained of transmission or of viraemia in any of the 34 children. These preliminary results are encouraging and if confirmed by more extensive studies should provide a sound basis for prophylaxis of rubella.

REFERENCES

Achs, R., Harper, R. G., and Siegel, M. (1966). Unusual dermatoglyphic findings associated with rubella embryopathy. New Engl. F. Med., 274, 148. 
Ainger, L. E., Lawyer, N. G., and Fitch, C. W. (1966). Neonatal rubella myocarditis. Brit. Heart f., 28, 691.

Alford, C. A., Jr. (1965). Studies on antibody in congenital rubella infections. I. Physicochemical and immunologic investigations of rubella neutralizing antibody. Amer. F. Dis. Child., 110, 455. , and Kanich, L. S. (1966). Congenital rubella: a review of virologic and serologic phenomena after maternal rubella in the first trimester. Sth. med. F. (Bgham, Ala.), 59, 745.

—, Neva, F. A., and Weller, T. H. (1964). Virologic and serologic studies on human products of conception after maternal rubella. New Engl. F. Med., 271, 1275.

Avery, G. B., Monif, G. G. R., Sever, J. L., and Leikin, S. L. (1965). Rubella syndrome after inapparent maternal illness. Amer. F. Dis. Child., 110, 444.

Banatvala, J. E., Horstmann, D. M., Payne, M. C., and Gluck, L. (1965). Rubella syndrome and thrombocytopaenic purpura in newborn infants. New Engl. F. Med., 273, 474.

Barr, B., and Lundström, R. (1961). Deafness following maternal rubella. Retrospective and prospective studies. Acta otolaryng. (Stockh.), 53, 413.

Bayer, W. L., Sherman, F. E., Michaels, R. H., Szeto, I. L. F., and Lewis, J. H. (1965). Purpura in congenital and acquired rubella. New Engl. f. Med., 273, 1362.

Bellanti, J. A., Artenstein, M. S., Olson, L. C., Buescher, E. L., Luhrs, C. E., and Milstead, K. L. (1965). Congenital rubella. Clinicopathologic, virologic, and immunologic studies. Amer. f. Dis. Child., 110, 464.

Beswick, R. C., Warner, R., and Warkany, J. (1949). Congenital anomalies following maternal rubella. ibid., 78, 334.

Bradford Hill, A., Doll, R., Galloway, T. McL., and Hughes, J. P. W. (1958). Virus diseases in pregnancy and congenital defects. Brit. F. prev. soc. Med., 12, 1.

Brody, J. A., Sever, J. L., McAlister, R., Schiff, G. M., and Cutting, R. (1965a). Rubella epidemic on St. Paul Island in the Pribilofs, 1963. I. 7. Amer. med. Ass., 191, 619.

,-- , and Schiff, G. M. (196jb). Prevention of rubella by gamma globulin during an epidemic in Barrow, Alaska, in 1964. New Engl. 7. Med., 272, 127.

Brown, G. C., Maassab, H. F., Veronelli, J. A., and Francis, T., Jr. (1965). Detection of rubella antibodies in human serum by the indirect fluorescent antibody technique. Arch. ges. Virusforsch., 16, 459

Buescher, E. L. (1964). In Diagnostic Procedures for Viral and Rickettsial Diseases, 3rd ed. The American Public Health Association, New York.

- (1965). Behavior of rubella virus in adult populations. Arch. ges. Virusforsch., 16, 470.

Butler, N. R., Dudgeon, J. A., Hayes, K., Peckham, C. S., and Wybar, K. C. (1965). Persistence of rubella antibody with and without embryopathy. Brit. med. F., 2, 1027.

Carruthers, D. G. (1945). Congenital deaf-mutism as a sequela of rubella-like maternal infection during pregnancy. Med. $\mathcal{F}$. Aust., 1, 315.

Clayton-Jones, E. (1947). Rubella as a cause of congenital deafness in England. Lancet, 1, 56.

Cooper, L. Z., Green, R. H., Krugman, S., Giles, J. P., and Mirick, G. S. (196ja). Neonatal thrombocytopenic purpura and other manifestations of rubella contracted in utero. Amer. F. Dis. Child., 110, 416.

$-\longrightarrow,-,-$, and $-(1965 \mathrm{~b})$. Rubella in contacts of infants with rubella-associated anomalies. Morbidity and Mortality Weekly Report, 14, 44.

- and Krugman, S. (1966). Diagnosis and management: congenital rubella. Pediatrics, $37,335$.

Dudgeon, J. A. (1965). Serological studies on the rubella syndrome. Arch. ges. Virusforsch., 16, 501.

(1966). Virus infections of the foetus. Proc. roy. Soc. Med., $59,1084$.

—, Butler, N. R., and Plotkin, S. A. (1964). Further serological studies on the rubella syndrome. Brit. med. F., 2, 165.

Enders, J. F., Weller, T. H., and Robbins, F. C. (1949). Cultivation of the Lansing strain of poliomyelitis virus in cultures of various human embryonic tissues. Science, 109, 85.

Erickson, C. A. (1944). Rubella early in pregnancy causing congenital malformations of eyes and heart. f. Pediat., 25, 281.

Franceschetti, A., and Bourquin, J. B. (1946). Rubéole pendant la grossesse et malformations congenitales de l'enfant. Ann. Oculist. (Paris), 179, 623.
Fraser, G. R. (1964). Profound childhood deafness. F. med. Genet., 1, 118

Friedmann, I., and Wright, M. I. (1966). Histopathological changes in the foetal and infantile inner ear caused by maternal rubella. Brit. med. F., 2, 20.

Giles, J. P., Cooper, L. Z., and Krugman, S. (1965). The rubella syndrome. Ұ. Pediat., 66, 434.

Grayston, J. T., and Watten, R. H. (1959). Epidemic rubella in Taiwan 1957-58. III. Gamma globulin in the prevention of rubella. New Engl. 7. Med., 261, 1145.

Green, R. H., Balsamo, M. R., Giles, J. P., Krugman, S., and Mirick, G. S. (1964). Studies on the experimental transmission, clinical course, epidemiology and prevention of rubella. Trans. Ass. Amer. Phycns, 77, 118. ,,--- , and - (1965a). Studies of the natural history and prevention of rubella. Amer. F. Dis. Child., 110, 348 - and $-(1965 \mathrm{~b})$. Experimental studies with rubella: evaluation of gamma globulin for prophylaxis. Arch. ges. Virusforsch., 16, 513.

Gregg, N. McA. (1941). Congenital cataract following German measles in the mother. Trans. ophthal. Soc. Aust., 3, 35. (1944). Further observations on congenital defects in infants following maternal rubella. ibid., 4, 119.

Grönvall, H., and Selander, P. (1948). Några virus-sjukdoma under graviditet och deras verkan pả fostret. Nord. Med., 37, 409.

Hagelsteen, H. (1946). Medfødte misdannełser som følge av rubeola hos moren $\mathrm{i}$ de første svangerskapsmåneder. $T$. norske Lageforen., 66, 677.

Hambidge, K. M., Shaffer, D., Marshall, W. C., and Hayes, K. (1966). Congenital rubella: report of two cases with generalised infection. Brit. med. $\mathcal{F}$., $1,650$.

Hayes, K., Dudgeon, J. A., and Soothill, J. F. (1967). Complementfixing antibodies in congenital rubella. To be published.

Hess, A. F. (1914). German measles (rubella): an experimental study. Arch. intern. Med., 13, 913.

Heggie, A. D. (1966). Rubella: current concepts in epidemiology and teratology. Pediat. Clin. N. Amer., 13, 251.

-, and Weir, W. C. (1964). Isolation of rubella virus from a mother and fetus. Pediatrics, 34, 278.

Hiro, Y., and Tasaka, S. (1938). Die Röteln sind eine viruskrankheit. Mschr. Kinderheilk., 76, 328.

Hope Simpson, R. E. (1944). Rubella and congenital malformations. Lancet, 1, 483.

Horstmann, D. M., Banatvala, J. E., Riordan, J. T., Payne, M. C., Whittemore, R., Opton, E. M., and Florey, C. duVe (1965a). Maternal rubella and the rubella syndrome in infants. Epidemiologic, clinical and virologic observations. Amer. F. Dis. Child., 110, 408.

-, Riordan, J. T., Ohtawara, M., and Niederman, J. C. (1965b). A natural epidemic of rubella in a closed population. Arch. ges. Virusforsch., 16, 483.

Jackson, A. D. M., and Fisch, L. (1958). Deafness following maternal rubella: Results of a prospective investigation. Lancet, 2, 1241.

Kay, H. E. M., Peppercorn, M. E., Porterfield, J. S., McCarthy, K., and Taylor-Robinson, C. H. (1964). Congenital rubella infection of a human embryo. Brit. med. F., 2, 166.

Korns, R. F. (1952). Prophylaxis of German measles with immune serum globulin. F. infect. Dis., 90, 183.

Korones, S. B., Ainger, L. E., Monif, G. R. G., Roane, J., Sever, J. L., and Fuste, F. (1965). Congenital rubella syndrome: study of 22 infants. Myocardial damage and other clinical aspects. Amer. 7. Dis. Child., 110, 434.

Krugman, S., and Ward, R. (1954). The rubella problem. Clinical aspects, risk of fetal abnormality, and methods of prevention. 7. Pediat., 44, 489.

- - , Jacobs, K. G., and Lazar, M. (1953). Studies on rubella immunization. I. Demonstration of rubella without rash. F. Amer. med. Ass., 151, 285.

Lambert, H. P., Stern, H., and Wellsteed, A. J. (1965). Congenital rubella syndrome. Lancet, $2,826$.

Lancaster, H. O. (1954). The epidemiology of deafness due to maternal rubella. Acta genet. (Basel), 5, 12.

Landon, J. F., Bess, M., Davidsson, H. B., Foote, F., and Muckenfuss, R. (1949). The efficiency of gamma globulin in the prevention of German measles. N.Y. Med., 5, 21.

Leuch, G. (1892). Klinische Beiträge zu den Krankheiten des Pulmonalostium. Z. klin. Med., 21, 142. 
Lindquist, J. M., Plotkin, S. A., Shaw, L., Gilden, R. V., and Williams, M. L. (1965). Congenital rubella syndrome as a systemic infection: studies of affected infants born in Philadelphia, U.S.A. Brit. med. F., 2, 1401.

Lundström, R. (1952). Rubella during pregnancy: its effects upon perinatal mortality, the incidence of congenital abnormalities and immaturity. A preliminary report. Acta paediat. (Uppsala), 41, 583.

- (1962). Rubella during pregnancy. A follow-up study of children born after an epidemic of rubella in Sweden 1951. With additional investigations on prophylaxis and treatment of maternal rubella. ibid., Suppl. 133.

- (1965). Passive immunization against rubella. Arch. ges. Virusforsch., 16, 506.

—, Svedmyr, A., Hagbard, L., and Kaijser, K. (1967). Rubella immunity as related to age and history of overt disease. Acta paediat. (Uppsala). In the press.

McCarthy, K., Taylor-Robinson, C. H., and Pillinger, S. E. (1963). Isolation of rubella virus from cases in Britain. Lancet, 2, 593.

McDonald, J. C. (1963). Gamma-globulin for prevention of rubella in pregnancy. Brit. med. $\mathcal{F}$., 2, 416.

-, and Peckham, C. S. (1967). Gamma globulin in the prevention of rubella in pregnancy. (To be published.)

Manson, M. M., Logan, W. P. D., and Loy, R. M. (1960). Rubella and other virus infections during pregnancy. Rep. on publ. Hlth med. Subj., 101.

Martin, S. M. (1945). Congenital defects and rubella. Brit. med. f., $1,855$.

- (1946). Deafness from rubella in pregnancy. ibid., $1,588$.

Menser, M. A., Dorman, D. C., Reye, R. D. K., and Reid, R. R. (1966). Renal-artery stenosis in the rubella syndrome. Lancet, 1, 790.

Meyer, H. M., Jr., Parkman, P. D., and Panos, T. C. (1966). Attenuated rubella virus. II. New Engl. f. Med., 275, 575.

Monif, G. R. G., and Sever, J. L. (1966). Chronic infection of the central nervous system with rubella virus. Neurology (Minneap.), 16, 111.

Naeye, R. L., and Blanc, W. (1965). Pathogenesis of congenital rubella. F. Amer. med. Ass., 194, 1277.

Parkman, P. D., Buescher, E. L., and Artenstein, M. S. (1962). Recovery of rubella virus from army recruits. Proc. Soc. exp. Biol. (N.Y.), 111, 225.

- Meyer, H. M., Jr., Kirschstein, R. L., and Hopps, H. E. (1966). Attenuated rubella virus. I. New Engl. f. Med., 275, 569.

,-- , and others (1966). Title as yet unknown. To be published.

Patrick, P. R. (1948). Report of a survey of children born in 1941 with reference to congenital abnormalities arising from maternal rubella. Med. F. Aust., 1, 421.

Pitt, D., and Keir, E. H. (1965). Results of rubella in pregnancy. ibid., 2, 647, 691, and 737 .

Plotkin, S. A. (1964). Virologic assistance in the management of German measles in pregnancy. F. Amer. med. Ass., 190, 265.

-, Boué, A., and Boué, J. G. (1965a). The in vitro growth of rubella virus in human embryo cells. Amer. F. Epidem., 81, 71.

- , Cochran, W., Lindquist, J. M., Cochran, G., Schaffer, D. B., Scheie, H. G., and Furukawa, T. (1967). The congenital rubella syndrome in late infancy. F. Amer. med. Ass. In the press.

—, Dudgeon, J. A., and Ramsay, A. M. (1963). Laboratory studies on rubella and the rubella syndrome. Brit. med. $\mathcal{F}$., 2 , 1296.

—, Oski, F. A., Hartnett, E. M., Hervada, A. R., Friedmann, S., and Gowing, J. (1965b). Some recently recognised manifestations of the rubella syndrome. F. Pediat., 67, 182.

Reese, A. B. (1944). Congenital cataract and other anomalies following German measles in the mother. Amer. F. Ophthal., 27, 483.

Reid, R. R., Murphy, A. M., Gillespie, A. M., Dorman, D. C., Menser, M. A., Hertzberg, R., and Harley, J. D. (1966). Isolation of rubella virus from congenital cataracts removed at operation. Med. F. Aust., 1, 540.

Rhodes, A. J. (1961). Virus infections and congenital malformation. In First International Conference on Congenital Malformations, p. 106. J. B. Lippincott, Philadelphia and Montreal.

Rones, B. (1944). The relationship of German measles during pregnancy to congenital ocular defects. Med. Ann. D.C., 13, 285.
Rubella symposium (1965). Amer. F. Dis. Child., 110, 345.

Rudolph, A. J., Singleton, E. B., Rosenberg, H. S., Singer, D. B., and Phillips, C. A. (1965). Osseous manifestations of the congenital rubella syndrome. ibid., 110, 428.

Schiff, G. M., Smith, H. D., Dignan, P. St. J., and Sever, J. L. (1965a). Rubella: studies on the natural disease. The significance of antibody status and communicability among young women. Amer. F. Dis. Child., 110, 366.

-, Sutherland, J. M., Light, I. J., and Bloom, J. E. (1965b). Studies on congenital rubella. Preliminary results on the frequency and significance of presence of rubella virus in the newborn and the effect of $\gamma$-globulin in preventing congenital rubella. ibid., 110, 441 .

Selzer, G. (1963). Virus isolation, inclusion bodies, and chromosomes in a rubella-infected human embryo. Lancet, $2,336$.

(1964). Rubella in pregnancy: virus isolation and inclusion bodies. S. Afr. F. Obstet. Gynaec., 2, 5.

Sever, J. L., Brody, J. A., Schiff, G. M., McAlister, R., and Cutting, R. $(1965 \mathrm{j})$. Rubella epidemic on St. Paul Island in the Pribilofs, 1963. II. F. Amer. med. Ass., 191, 624.

- , Huebner, R. J., Castellano, G. A., Sarma, B. S., Fabiyi, A., Schiff, G. M., and Cusumano, C. L. (1965b). Rubella complement fixation test. Science, 148, 385.

-, - - Fabiyi, A., Monif, G. R., Castellano, G., Cusumano, C. L., Traub, R. G., Ley, A. C., Gilkeson, M. R., and Roberts, J. M. (1966). Antibody responses in acute and chronic rubella. Proc. Soc. exp. Biol. (N.Y.), 122, 513.

- Nelson, K. B., and Gilkeson, M. R. (1965c). Rubella epidemic, 1964: effect on 6,000 pregnancies. I. Preliminary clinical and laboratory findings through the neonatal period: a report from the collaborative study on cerebral palsy. Amer. F. Dis. Child., 110, 395.

—, Schiff, G. M., Bell, J. A., Kapikian, A. Z., Huebner, R. J., and Traub, R. G. (196jd). Rubella: frequency of antibody among children and adults. Pediatrics, 35, 996.

Sheridan, M. D. (1964). Final report of a prospective study of children whose mothers had rubella in early pregnancy. Brit. med. F., 2, 536.

Singleton, E. B., Rudolph, A. J., Rosenberg, H. S., and Singer, D. B. (1966). The roentgenographic manifestations of the rubella syndrome in newborn infants. Amer. F. Roentgenol., 97, 82.

Soothill, J. F., Hayes, K., and Dudgeon, J. A. (1966). The immunoglobulins in congenital rubella. Lancet, 1, 1385.

Stern, H. (1965). Rubella virus complement-fixation test. Nature (Lond.), 208, 200.

Swan, C. (1949). Rubella in pregnancy as an aetiological agent in congenital malformations, stillbirths, miscarriage and abortion. 7. Obstet. Gynaec. Brit. Emp., 56, 341 and 591.

_- Tostevin, A. L., and Black, G. H. B. (1946). Final observations on congenital defects in infants following infectious diseases during pregnancy with, special reference to rubella. Med. F. Aust., $2,889$.

- - Moore, B., Mayo, H., and Black, G. H. B. (1943). Congenital defects in infants following infectious diseases during pregnancy. With special reference to the relationship between German measles and cataract, deaf-mutism, heart disease and microcephaly, and to the period of pregnancy in which the occurrence of rubella is followed by congenital abnormalities. ibid., 2, 201.

Thorburn, M., and Miller, C. G. (1967). The pathology of congenital rubella in Jamaica. Arch. Dis. Childh. In the press.

Wardrop, J. (1813). History of James Mitchell, a Boy Born Blind and Deaf, with an Account of the Operation Performed for the Recovery of his Sight. Murray, London.

Watson, G. I., and McDonald, J. C. (1963). The infectiousness of rubella. Report by the epidemic observation unit of the College of General Practitioners. Brit. med. F., 2, 419.

Weiss, D. I., Cooper, L. Z., and Green, R. H. (1966). Infantile glaucoma. F. Amer. med. Ass., 195, 725.

Weller, T. H., Alford, C. A., Jr., and Neva, F. A. (1964). Retrospective diagnosis by serologic means of congenitally acquired rubella infections. New Engl. F. Med., 270, 1039.

$\longrightarrow$, and Neva, F. A. (1962). Propagation in tissue culture of cytopathic agents from patients with rubella-like illness. Proc. Soc. exp. Biol. (N.Y.) 111, 215.

Wesselhoeft, C. (1949). Rubella (German measles) and congenital deformities. New Engl. F. Med., 240, 258. 